\title{
MICROBIOLOGICAL QUALITY AND SAFETY ASSESSMENT OF CAMEL MILK (CAMELUS DROMEDARIES) IN SAUDI ARABIA (QASSIM REGION)
}

\author{
M. G. EL-ZINEY ${ }^{1,2^{*}}-$ A. I. AL-TURKI ${ }^{3}$ \\ ${ }^{I}$ Department of Dairy Science and Technology, Faculty of Agriculture-Al Shatby, Alexandria \\ University, Alexandria, Egypt \\ ${ }^{2}$ Department of Food Science and Human Nutrition \\ ${ }^{3}$ Department of Plant Production and Protection, College of Agriculture and Veterinary \\ Medicine, Qassim University, P.O. Box 1482, 51431 Buraidah, Saudi Arabia \\ (phone: +966-6-3800050 ext 2361, fFax: +966-6-3801360) \\ e-mail:elziney@yahoo.com
}

(Received $5^{\text {th }}$ May 2006; accepted $13^{\text {th }}$ May 2007)

\begin{abstract}
The microbiological quality and safety of raw camel milk from different farms in Qassim region (middle Saudi Arabia) were examined. Milk samples ( $n=33$ ) were aseptically collected from the milking bowls. Samples were analyzed for several microbial quality attributes including aerobic total plate count (ATPC), psychrotrophs (PC), aerobic mesophilic sporeforming bacteria (AMSC), Enterobacteriaceae, total coliforms, faecal coliforms and moulds and yeasts. Furthermore, the presence of selected pathogens such as Staphylococcus aureus and Salmonella was detected. The mean log counts per ml for ATPC, psychrotrophs, aerobic mesophilic spore former, Enterobacteriaceae, and moulds and yeasts were 5.0, 3.8, 2.1, 2.7, and 1.9, respectively. Coliform group was found in $45.5 \%$ of samples while $12 \%$ were faecal coliform positive as revealed by MPN method. S. aureus was located in $70 \%$ of the samples and the mean count was $2.7 \mathrm{log}$ cfu per ml. Meanwhile, salmonella was detected in $24 \%$ of the samples. Results indicate the potential health risk of consuming raw camel milk under the present production conditions.
\end{abstract}

Keywords: camel milk, aerobic total count, psychrotrophs, coliforms, aerobic spore former, S. aureus, Salmonella

\section{Introduction}

Nowadays, public health concern associated with microbial food safety has arisen. Numerous epidemiological reports have implicated non-heat treated milk and raw-milk products as the major factors responsible for illnesses caused by food-borne pathogens $[9,19]$. Cross-contamination with pathogenic microorganisms can gain access to milk either by faecal contamination or by direct excretion from the udder into milk.

Camel meat and milk are the key foods in arid and semi-arid areas of the African and Asian countries, especially in Saudi Arabia. Food Agriculture Organization has reported that more than 18 million camels around the world support the survival of millions of people [14]. Camel milk not only contains more nutrients compared to cow milk [1], but also it has therapeutic and antimicrobial agents $[4,12]$. Saudi Arabia produced over one percent of world stocks of camels (425,000 head). In regard to camel milk production, Saudi is globally ranked at the seventh position (89,500 cubic metres) [14].

In fact, most of camel milk is consumed in the raw state without any heat treatments or acid fermentation and kept at high ambient temperature coupled with lack of refrigeration facilities during milking and transporting. These conditions turn the milk to be unsafe, capable of causing food-borne diseases and it even spoil fast. 
In Qassim area, as in many regions around the kingdom, camel milk is produced in traditional way by hand milking, handled and transported under low hygienic measures. However, there is no reports documented any outbreak related to unpasteurized (raw) camel milk. Furthermore, there is a limited data on the microbial assessment of raw camel milk $[2,29,5]$. Furthermore, in view of its health benefits, there is a fast growing demand for raw camel milk in Saudi Arabia and further it is expected to be introduced as a new functional food in the European market. Therefore, there is a high necessity to find out about the present hygienic situation regarding the raw camel milk in Qassim area.

The aim of the present study were (1) to assess the microbial quality of raw camel milk in Saudi Arabia (Qassim area) using several microbial quality attributes including aerobic total plate count, aerobic mesophilic spore count, psychrotrophic count, and moulds and yeasts (2) to study the prevalence of a variety of indicator organisms (Nitrobacteria, and total and faecal coliforms) and food-borne pathogens, with reference to Staphylococcus aureus and Salmonella spp.

\section{Materials and methods}

\section{Milk samples}

Between February and May 2005, a total of thirty-three-bulk camel milk samples were collected from different locations in Qassim area (middle Saudi Arabia). Milk was collected from camels by hand milking as normally practiced by the farmers in except of the experimental station of animal production of the college of agriculture and veterinary medicine, Qassim University, which introduced the mechanical milking of camels. The samples were collected in sterile screw bottles kept in cool boxes until transported to the laboratory. The samples were analyzed within $24 \mathrm{~h}$.

\section{Microbiological analysis}

Milk samples $(25 \mathrm{ml})$ were diluted in buffered peptone saline $(225 \mathrm{ml}, 0.5 \% \mathrm{w} / \mathrm{v}$; peptone; $0.85 \% \mathrm{w} / \mathrm{v} ; \mathrm{NaCl}$ ), mixed in stomacher bag and stomached in Seward stomacher (Seward 400, England) for 2 minutes. In order to quantify the various microbial groups, appropriate dilutions were surface plated. Aerobic total plate count (ATPC) was carried out on plate count agar (PCA), incubated at $32^{\circ} \mathrm{C}$ for $72 \mathrm{~h}$ [23]. For aerobic mesophilic spore count (AMSC), the milk was heat-shocked at $80^{\circ} \mathrm{C}$ for $10 \mathrm{~min}$ to destroy vegetative cells. After being cooled in an ice bath, the milk was immediately plated on plate count agar and incubated at $32{ }^{\circ} \mathrm{C}$ for $48 \mathrm{~h}$ [23]. Psychrotrophic count (PC) was performed by incubation of appropriate dilutions on PCA kept at $7^{\circ} \mathrm{C}$ for $10 \mathrm{~d}$ [23].

For enumeration of members of the family of Enterobacteriaceae, eosine methylene blue agar (modified) Levine (EMB) was used $\left(35^{\circ} \mathrm{C}\right.$ for $\left.24 \mathrm{~h}\right)$. Total and faecal coliforms were determined by MPN method according to US standard method [15]. The enumeration of moulds and yeasts was done on potato dextrose agar (PDA) acidified by lactic acid 10\% (Oxoid, SR21).

Staphylococcus aureus was enumerated on Baird Parker agar supplemented with egg yolk enrichment at $37^{\circ} \mathrm{C}$ for $48 \mathrm{~h}$. Black shiny colonies surrounded by hello zone were 
examined microscopically and tested for catalase, coagulase and staphylase production using Oxoid reagents according to the manufacturer's instructions.

Salmonella spp. was detected as it is previously described by Andrews and Jacobson [3]. A portion of $25 \mathrm{ml}$ of milk was pre-enriched in $225 \mathrm{ml}$ of buffered peptone water at $37^{\circ} \mathrm{C}$ for $24 \mathrm{~h}$. Then, $1 \mathrm{ml}$ of pre-enrichment sample was incubated in $10 \mathrm{ml}$ cystine selenite broth and Rappaport-Vassiliadis broth at $37^{\circ} \mathrm{C}$ for $24 \mathrm{~h}$. Selective enrichments were then streaked onto bismuth sulphite, xylose lysine desoxycholate (XLD) and Hekton entreic agars. All selective media were incubated at $37^{\circ} \mathrm{C}$ for $24 \mathrm{~h}$. Typical colonies were examined by microscope, characteristics of growth on lysine iron agar, negative of urease production and then tested with Salmonella polyvalent O antiserum (Salmonella latex test, Oxoid FT0203). Isolates with typical reactions for salmonella were then confirmed by using API 20E identification kit (BioMérieux, France). Unless otherwise stated, all the media and supplements used throughout the present study were purchased from Oxoid (Oxoid, Basingstoke, Hampshire, England)

\section{Statistical analysis}

Descriptive and correlation analysis between the different microbial parameters were performed using SPSS software (Version 10, SPSS Inc., Chicago)

\section{Results and discussions}

The presence of the various microbial groups found in raw camel milk from the Qassim area is presented in (Figure 1 and Table 1.) The profile of total aerobic mesophilic bacteria in milk samples is shown in (Fig. 1A). The mean of TAPC in collected samples was $5 \mathrm{log} \mathrm{cfu} / \mathrm{ml}$ with a maximum of $7.15 \log \mathrm{cfu} / \mathrm{ml}$ (Table 1). These results are in agreement with those reported for Saudi (i.e., $5.4 \log \mathrm{cfu} / \mathrm{ml}$ in average) and Ethiopian (i.e. $5.6 \mathrm{log} \mathrm{cfu} / \mathrm{ml}$ in average) camel milk by Al Mohizea [2] and Semereab and Molla [29], respectively. It is worth to mention that there are no microbiological standards concerning camel milk. Therefore, the microbiological limit values for cow milk was used to assess the quality of camel milk. In our study, $54.5 \%$ $(\mathrm{n}=18)$ of ATPC results were within the accepted limits $(5.3-5.6 \log \mathrm{cfu} / \mathrm{ml})$ of APHA [23] and Directive 92/46/EEC [10].

The count of psychrotrophic bacteria was varied between samples. Approximately $30 \%$ of the samples had a psychrotrophic count (PC) of $\cong 1 \log \mathrm{cfu} / \mathrm{ml}$, with a mean value of $3.8 \mathrm{log} \mathrm{cfu} / \mathrm{ml}$ while the maximum was $6.82 \mathrm{log} \mathrm{cfu} / \mathrm{ml}$ (Fig 1B and Table 1). The results of psychrotrophs are comparable with average counts (3.3-3.7 log cfu/ml) reported for raw cow milk by Boor et al., [6] and Chye et al., [7]. Further, no information in the literature documented the content of psychrotrophs in camel milk. Psychrophilic bacteria are responsible for an increased production of proteinases and lipases, which can survive heat treatments (i.e. pasteurization) thus affecting the shelflife and quality of milk [18].

In terms of residual spore forming bacteria, approximately $60 \%$ of the samples had $>50$ aerobic mesophilic spore-formers/ml, with mean value of $2.1 \log \mathrm{cfu} / \mathrm{ml}$ (Fig $1 C$ and Table 1). These results are full within the ranges (i.e., $1.7 \mathrm{log} \mathrm{cfu} / \mathrm{ml}$ as a mean) for cow's milk found by Boor et al. [6]. No data in the in the literature reported the level of this group of organisms in raw camel's milk. Spore-forming bacteria are known to, apart from causing spoilage, cause food-poisoning by producing heat labile enterotoxins $[13,28]$. 
Yeasts and moulds were only detected in 19 samples $(57 \%)$ with the mean and maximum values of 1.9 and $5.65 \log \mathrm{cfu} / \mathrm{ml}$, respectively (Fig $1 \mathrm{D}$ and Table 1). The yeast and moulds content in Moroccan camel's milk was found to be high with an average raised to $4.6 \log \mathrm{cfu} / \mathrm{ml}$ [5]. In agreement with our results it is reported that the high counts of yeast and moulds in milk is rather uncommon as a result of natural milk $\mathrm{pH}$, causing bacteria to predominate $[16,27]$.

(A)

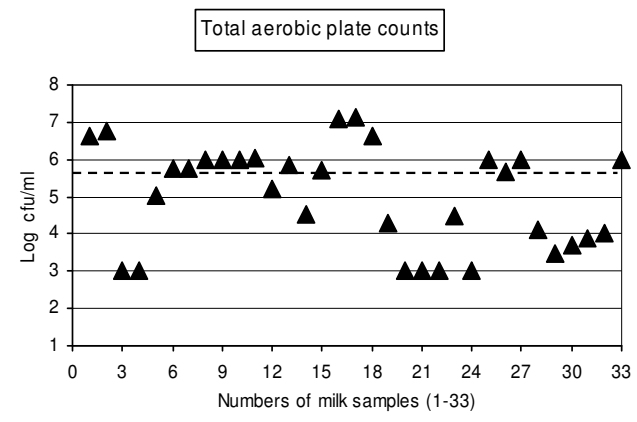

(C)

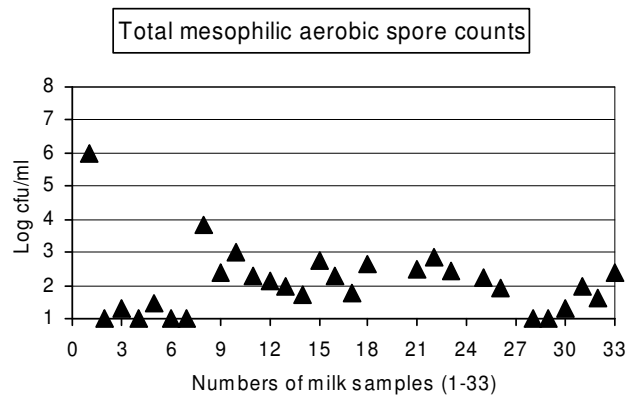

(E)

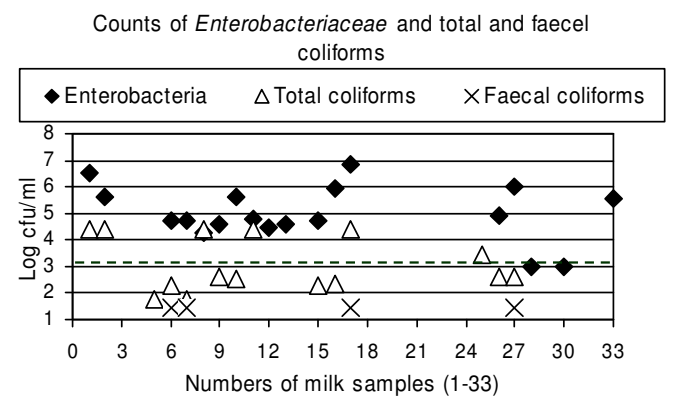

(B)

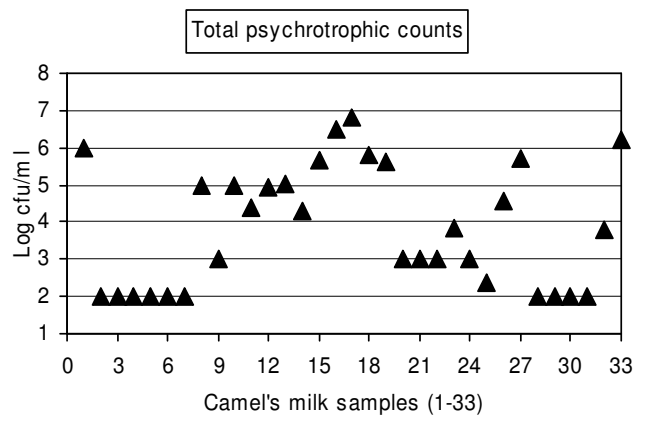

(D)

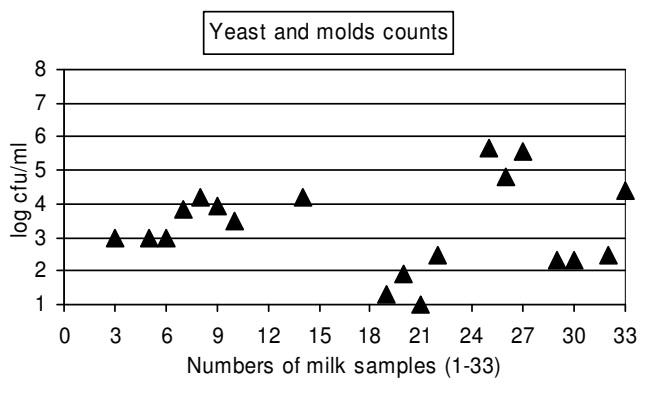

(F)

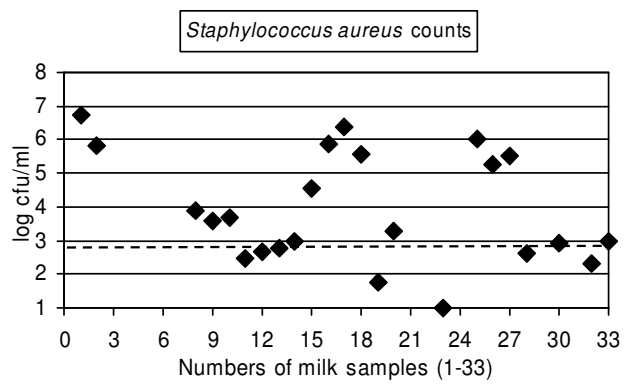

Figure 1. Patterns of total aerobic plate counts (A), psychrotrophs (B), aerobic mesophilic spore former $(D)$, yeast and moulds $(E)$, Enterobacteriaceae and total and faecal coliforms $(F)$ and Staphylococcus aureus in raw camel's milk $(n=33)$ collected from Qassim region. Dash line (-----) represents the EU standards. 
Table 1. Selected statistical values (log cfu/ml) of different microbial parameters detected in raw camel's milk.

\begin{tabular}{ccccc}
\hline Microbial parameter & Mean & Std. Dev & Maximum & Minimum \\
\hline Total aerobic plate counts & 5.0 & 1.36 & 7.15 & 3.0 \\
Psychrotrophic counts & 3.8 & 1.64 & 6.82 & 2.0 \\
Aerobic mesophilic spore & 2.1 & 0.98 & 6.0 & 1.0 \\
formers & & & & \\
Enterobacteriaceae & 2.72 & 2.63 & 6.82 & 0 \\
Total coliforms & 1.4 & 1.7 & 4.38 & 0 \\
Yeast and moulds & 1.9 & 1.93 & 5.65 & 0 \\
Staphylococcus aureus & 2.7 & 2.29 & 6.72 & 0 \\
\hline
\end{tabular}

Enterobacteriaceae were detected in 18 samples (54.5\%). The mean count value of EMB plates was $2.7 \mathrm{log} \mathrm{cfu} / \mathrm{ml}$, with a maximum of $6.82 \mathrm{log} \mathrm{cfu} / \mathrm{ml}$ (Fig $1 E$ and Table 1). The total coliform determined by MPN technique showed a positive result in 15 samples (45.5\%) with a maximum value of $4.2 \mathrm{log} \mathrm{cfu} / \mathrm{ml}$ (Fig $1 E$ ). Out of total coliforms positive samples (15), only four samples were positive for faecal coliforms which identified as $E$. coli by the growth on MacConkey plates and IMViC tests. The occurrence of total coliforms, in our study, was much lower than reported for Ethiopian raw camel's milk (100\%) by Semereab and Molla [29]. Further, Benkerroum et al. [5] demonstrated high total coliforms counts for Moroccan camel's milk (i.e., $6.8 \mathrm{log}$ $\mathrm{cfu} / \mathrm{ml}$ in average). In our study, six samples (18\%) were over the coliform limits fixed by the EC regulations for raw cow milk [10]. The Enterobacteriaceae family has earned a reputation placing them among the most pathogenic and most often encountered organisms in food. Enterobacteriaceae family includes coliform group (Escherichia, Enterobacter, Citrobacter and Klebsiella) in addition to many other genera (Salmonella, Shigella, Morganella, Providencia, Edwardseilla, Proteus, Serratia and Yersinia) which are isolated from animal intestine $[8,20]$. The existence of coliform bacteria may not necessary indicate a direct faecal contamination of milk, but precisely as an indicator for poor sanitary practices during milking and further handling processes. Moreover, the presence of faecal coliforms, i.e. E. coli implies a risk that other enteric pathogens may be present in the sample.

Nearly $70 \%(\mathrm{n}=23)$ of the collected samples were contaminated by $S$. aureus, with a mean count of $2.74 \log \mathrm{cfu} / \mathrm{ml}$, while the highest level of contamination reached to 6.72 $\log \mathrm{cfu} / \mathrm{ml}$ (Fig $1 F$ and Table 1). The existence rate of $S$. aureus, in the present study, was relatively high, however, the organism has been detected in all tested samples $(\mathrm{n}=12)$ in Morracan camel milk [5] with an average of $5.1 \mathrm{log} \mathrm{cfu} / \mathrm{ml}$. Semereab and Molla [29] reported that $S$. aureus isolates represent $15 \%$ of the total bacteria isolated from composite camel udder milk. The incidence of mastitis in camel herds (19.5\%) and the high frequency of $S$. aureus $(31.5 \%)$ as the casual agent may explain these results [25]. According to the EC standards for raw cow's milk intended for direct consumption [10], $51 \%(n=17)$ of the samples were found to have $S$. aureus counts higher than the fixed limit $(2.7 \mathrm{log} \mathrm{cfu} / \mathrm{ml})$. An overview of the annual reports of food-borne diseases from seven countries indicated that milk and milk products implicated in $1-5 \%$ of the total bacterial outbreaks. $S$. aureus was by far the most frequent pathogen associated with these outbreaks (85.5\%), followed by Salmonella (10\%) [9].

The incidence of Salmonella spp. was high as $8(24 \%)$ out of 33 milk samples were found to be positive for this organism. The reported isolation rate of this organism for raw cow milk was found to be within the range of 3-9\% [22]. However, sixteen percent 
of organ and faecal samples collected from healthy slaughtered camels were positive for Salmonella spp. [24]. Moreover, Huston et al. [21] reported that in $31 \%$ of the study dairy herds was shedding Salmonella spp.

Salmonella spp., are an infrequent cause of mastitis in dairy animals but several species of Salmonella have documented to colonize udders and shed at levels of up to 2000 cells/ml [17]. In addition, camel herds rarely benefit from veterinary care [25] with lack of using appropriate sanitizers between milking intervals, which could enhance the microbial colonization. These organisms pose a health risk to consumer if milk is consumed without any heat treatment. De Buyser et al. [9] reported that Salmonella spp is one of the most etiologic agents responsible for several outbreaks associated with the consumption of raw milk and milk products.

In the present study, the correlation analysis between pairs of different microbiological parameters was conducted in order to evaluate the correlate degree among it. The results showed no correlation coefficients above 0.8 . The highest positive correlation were found between ATPC and enterobacterial counts (0.77), ATPC and total coliforms (0.73), enterobacterial counts and total coliforms (0.668), ATPC and PC (0.58) and PC and aerobic mesophilic spore counts (AMSC, 0.544). All other correlation coefficients were below 0.5 .

The correlation value between ATPC and PC was low compared with those (i.e., 0.74 in average) reported by Peeler el al. [26] and Boor et al. [6], but a weak correlation (0.42) was found by Chye et al. [7]. It is suggested that these results might be affected by the differences between the climatic conditions between the countries involved in those studies and consequently reflected on the PC levels. The good correlation between PS and AMSC established in our study indicates the possibility of the wide spread of psychrotrophic Bacillus spp. These organisms have the ability to survive the pasteurization, grow secreted enzymes or metabolites and affected the milk quality during the cold storage. Correlations between ATPC and total coliforms (0.74), ATPC and faecal coliforms (0.38) and total coliforms and faecal coliforms (0.66) suggest that the contamination is likely to be not originated from faecal origin.

\section{Conclusion}

The outcome of the present results suggests that approximately $50 \%$ of the examined raw camel milk samples were produced and handled under poor hygienic conditions with high health risk to the consumers. Based on these findings, it is strongly recommended that large-scale research studies regarding the quality of raw camel milk, milking protocols and sanitizing programs should be conducted. Such studies will help to understand the behavioural risk factors associated with raw milk production, consumption and that educational programs will be developed to address issues connected to consumption of raw camel milk. The characteristics and especially the behaviour of isolated microorganisms show that the pathogens must be studied to explore the cycle of contamination and how these organisms are able to survive under severely arid conditions.

Acknowledgment. The authors would like to thank Omer Abu Giab for his technical assistance. This study was supported by a grant from the Agricultural and Veterinary Research Centre, College of Agriculture and Veterinary Medicine, Qassim University, Buriedah, Saudi Arabia. 


\section{REFERENCES}

[1] Arrowal, R.P., Beniwal, R. Kochar, D.K., Tuteja, F.C., Ghorui, S.K., Sahaui, M.S., Sharma, S. (2005): Camel milk as an adjunct to insulin therapy improves long-term glycaemia control and reduction in doses of insulin in patients with type-1 diabetes A 1 year randomized controlled trial. - Diabetes Res. Clin. Pract. 68:17

[2] Al Mohizea, I.S. (1994): Microbial quality of camel's milk in Riyadh markets. - Egyptian J. Dairy Sci. 14:469-487.

[3] Andrews, W.H., Jacobson, A. (2001): Salmonella - In: Bacteriological analytical manual online. www.cfsan.fda.gov.

[4] Barbour, E.K., Nabbut, N.H., Ferisch, W.M., Ai-Nakhli, H.M. (1984): Inhibition of pathogenic bacteria by camel's milk: relation to whey lysozyme and stage of lactation. J. Food Protec. 47: 838-840.25.

[5] Benkerroum, N., Boughdadi, A., Bennani, N., Hidane, K. (2003): Microbiological quality assessment of Moroccan camel's milk and identification of predominating lactic acid bacteria. - World J. Microbiol. Biotechnol. 14: 645-648.

[6] Boor, K.J., Brown, D.P., Murphy, S.C., Kozlowski, S.M., Bandler, D.K. (1998): Microbiological and chemical quality of raw milk in New York state. - J. Dairy Sci. 81: 1743-1748.

[7] Chye, F.Y., Abdullah, A., Ayob, M.K. (2004): Bacteriological quality and Safety of raw milk in Malaysia. - Food Microbiol. 21: 535-541.

[8] Collins, C.H., Lyne, P.M., Grange, J. (1995): Collins and Lyne,s microbiological methods. - Butterworth-Heinemann, London.

[9] De Buyser, M L., Dufour, B., Maire, M., Lafarge, V. (2001): Implication of milk and milk products in food-borne disease in France and different industrialized countries. - Int. J. Food Microbiol. 67: 1-17.

[10] European Commission (2001): Overview of microbiological criteria for foodstuffs in community legislation in force. - Online available at http://europa.eu.int/comm/food/fs/mr/mr_crit_en.pdf. Accessed April 11, 2003

[11] Elagamy, E.I., Abou-Shloue Zeinab, I., Abdel-Kader, Y.I. (1998): Gel electrophoresis of proteins, physicochemical characterization and vitamin $\mathrm{C}$ content of milk of different species. - Alex. J. Agric. Res., 43:57-70.

[12] Elagamy, E.I., Ruppanner, R., Ismail, A., Champagene, C.P., Assaf, R. (1992): Antimicrobial and antiviral activity of camel milk protective proteins. - J. Dairy Res. 59: 169-175.

[13] Eley, A.R. (1992): Infective bacterial food poisoning. - In: Eley, A.R. (Ed.), Microbial food poisoning. Chapman \& Hall, Sheffield. pp. 15-33.

[14] FAO (2003): Statistics year-book. - FAO, Rome.

[15] Federal Register (1990): Drinking water: national primary drinking water regulations; analytical techniques coliform bacteria proposed rule. - Fed. Proc. 55: 22752-22756.

[16] Frazier, W.C., Westhoff, A.D. (1988): Food Microbiology. - McGraw-Hill book Company, New York.

[17] Fontaine, R.E., Cohen, M.L., Martin, W.T., Vernon, T.M. (1980): Epidemic salmonellosis from cheddar cheese-surveillance and prevention. - Am. J. Epidemiol. 111: 247-254.

[18] Graaf, T., De Remoero Zuniga, J.I., Caballero, M., Duringar, R.H. (1997): Microbiological quality aspects of cow's milk at small holder cooperative in Turrialba. Costarica Rev. Elev. Med. Vet. Pays Trop. 50:57-64.

[19] Harrington, P., Archer, J., Davis, J.P., Croft, D.R., Varma, J.K., EIC officers (2002): Outbreak of Campylobacter jejuni infections associated with drinking unpasteurized milk through a cow-leasing program-Wisconsin, 2001. - MMWR 51: 548-549. 
[20] Hays, M.C., Raylea, R.C., Murphy, S.C., Carey, N.R., Scarlett, J.M., Boor, K.J. (2001): Identification and characterization of elevated microbial counts in bulk tank raw milk. - J. Dairy Sci. 84: 292-298

[21] Huston C.L., Wittum, T.E., Keen, J.E. (2002): Prevalence of Salmonella spp in dairy herds. - J. Am. Vet. Med. Assoc. 220: 645-649.

[22] Jayarao, B.M., Henning, D.R. (2001): Prevalence of foodborne pathogens in bulk tank milk. - J. Dairy Sci. 84: 2157-2162.

[23] Marshall, R.T. (1992): Standard methods for the examination of dairy products. $-16^{\text {th }}$ ed. American Public Health Association (APHA), Washington DC.

[24] Molla, B., Alemayehu, D., Salah, W. (2003): Source and distribution of Salmonella Serotypes isolated from food animals, slaughterhouse personnel and retail meat products in Ethiopia: 1997-2002. - Ethiop. J. Health Dev. 17: 63-70.

[25] Obeid, A.I., Bagadi, H.O., Mukhtar, M.M. (1996): Mastitis in Camelus dromedaries and the somatic cell content of camels' milk. - Res. Vete. Sci. 61: 55-58.

[26] Peeler, T.J., Messer, W., Sanders, R.L., Bachelor, H.K. (1989): Comparison of preliminary incubation counts and standard plate counts of Grad A bulk tank milk from eleven states. - Dairy Food Environ. Sanit. 9: 494-497.

[27] Pitt, J.I., Hocking, A.D. (1997): Fungi and food spoilage. - Blackie Academic and Professional, London.

[28] Reed, G. H. (1994): Food-borne illness (Part4) Bacillus cereus gastroenteritis. - Dairy, Food Environ. Sanitation 14: 87-95.

[29] Semereab, T., Molla, B. (2001): Bacteriological quality of raw milk of camel (Camelus dromedarius) in AFAR region (Ethiopia). - J. Camel Res. 8: 51-54. 